\title{
環境電子顕微鏡（ETEM）による反応挙動その場観察
}

\author{
川㠃 忠寬 1 ,* \\ 1 一般財団法人ファインセラミックスセンター ナノ構造研究所 \\ 广 456-8587 愛知県名古屋市熱田区六野2-4-1 \\ *t_kawasaki@jfcc.or.jp
}

(2019 年 11 月 6 日受理 ; 2020 年 1 月 28 日掲載決定)

環境電子顕微鏡（Environmental Transmission Electron Microscopy; ETEM）は, 透過型電子顕微鏡（TEM）を 用いた動的観察手法のひとつである。通常の TEM では，電子ビームの残留ガス分子による散乱を抑制するた め, 試料は真空下に置かれることになる。これに対して, ETEM では, ガス雾囲気や液中など材料が実際に動 作する状況下における状態を直接観察することが可能である. 本稿では, 2 つのタイプの ETEM についてその 原理や特徴を概説する.また, 応用研究の例として, 金ナノ触媒反応のガス雾囲気下その場観察，およびグラ フェンを用いた液中観察の結果を示す.

\section{In-situ Observations of Reactions with Environmental Transmission Electron Microscopy}

\author{
Tadahiro Kawasaki ${ }^{1, *}$ \\ ${ }^{1}$ Nanostructures Research Laboratory, Japan Fine Ceramics Center, \\ 2-4-1 Mutsuno, Atsuta-ku, Nagoya 456-8687, Japan \\ *t_kawasaki@jfcc.or.jp
}

(Received: November 6, 2019; Accepted: January 28, 2020)

\begin{abstract}
ETEM is a dynamic observation technique based on transmission electron microscopy (TEM). In normal TEMs, specimens are set under vacuum condition because electron scattering by air molecules must be minimized. In contrast, ETEM enables to observe specimens immersed in gas or liquid environments. Therefore, ETEM can reveal nature of materials under the conditions in which they are formed or utilized, for example, catalysts in gas, battery electrodes in liquid electrolyte, and so on. This paper describes principles and features of two types of the ETEM, and also demonstrates effectiveness of this technique by introducing application results on gas reaction of gold nanoparticulate catalyst and high-resolution imaging in liquid environment.
\end{abstract}

\section{1. はじめに}

透過型電子顕微鏡（TEM）は材料の非常に重要な 解析手段のひとつである. 通常, TEM の試料は高 真空下（10-4 $10^{-6} \mathrm{~Pa}$ 程度）に置かれるが，触媒材 料などの場合, 周囲の環境によって構造が変化する 可能性があるため，それらが実際に使用される環境 下での観察が望まれる。このような要求を満たすた
め, 1960 年初頭から環境制御型電子顕微鏡

(Environmental Transmission Electron Microscope; ETEM）の開発が始められ [1-5]，近年ではガス雰囲 気や液中でのその場観察が数多く報告されるように なっている [6-15]. 一般的な電子顕微鏡の内部は, 電子ビームの直進を阻害しないよう高真空に保たれ ており，試料室も真空となっている。このため，上 
述したような気・液雾囲気を電子顕微鏡内部に実現 するために, ETEM は特殊な機構を備えている。 そ の機構には大きく分けて 2 つのタイプがある. 1 つ が『開放型』と呼ばれるもので, TEM 本体の電子線 通路に数カ所の作動排気系を追加設置することで, 試料室にガスを導入しながら電子銃部の真空を維持 できる機構となっている [6-11]. もう一方の ETEM は『隔膜型』と呼ばれるタイプで, 配管を内蔵した 特殊 TEM 試料ホルダーを用いることで, 真空外か ら試料部分にガスや液体を導入出することが可能で ある [12-16]. 試料周囲に導入されたガス等は, 隔 膜と呼ばれる厚さ数 $10 \mathrm{~nm}$ 以下の薄膜でシールされ ており，周囲に拡散しないようになっている。

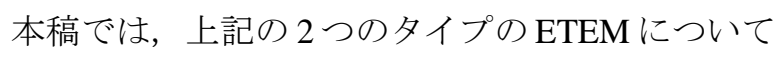
詳述するとともに, 応用研究の例としてナノ粒子金 触媒のプロピレン酸化反応その場観察を行った結果 について述べる.

\section{2. 環境電子顕微鏡の原理と特徵}

前述のとおり, ETEM は (a)開放型（差動排気型） と (b)隔膜型の 2 種類に分類される（Fig. 1）.

開放型では，電子線経路の途中（特に試料室の上 下)に，電子線を通すための小孔を有する遮蔽板(才 リフィス）を取り付けることで, 経路に沿ったガス の拡散を抑制する. 更に小孔から漏れるガスを追加 のポンプで排気する差動排気系を構築することで, 試料室にガスを導入しても, その周囲を真空に保つ ことが可能となる. 導入できるガスの圧力は差動排 気能力に依るため, 比較的高圧 $\left(\sim 10^{3} \mathrm{~Pa}\right.$ 以上 $)$ の 環境を実現するためには，差動排気系を多段に重㸚
る，個々の排気速度を上げる等が必要である. 前述 のとおり，ETEM は (a)開放型（差動排気型）と(b) 隔膜型の 2 種類に分類される (Fig. 1).

開放型では，電子線経路の途中（特に試料室の上 下) に，電子線を通すための小孔を有する遮蔽板(才 リフィス）を取り付けることで, 経路に沿ったガス の拡散を抑制する. 更に小孔から漏れるガスを追加 のポンプで排気する差動排気系を構築することで, 試料室にガスを導入しても，その周囲を真空に保つ ことが可能となる．導入できるガスの圧力は差動排 気能力に依るため, 比較的高圧 $\left(\sim 10^{3} \mathrm{~Pa}\right.$ 以上) の 環境を実現するためには, 差動排気系を多段に重政 る，個々の排気速度を上げる等が必要である.

開放型の長所は, (1)高空間分解能観察が可能であ る．本方式では電子線を阻害するものが比較的少な い（ガス分子の量が少なく, 隔膜も無い）ためであ る. (2)試料ホルダーに自由度がある. 本方式では試 料ホルダーには手を加える必要が無いため, 従来通 りの各種ホルダーをそのまま利用することが出来る. 即ち, 2 軸傾斜 · 加熱 - 冷却 - 電圧印加 - 応力変形 などをガス雾囲気下で実施することが可能である.

一方で, 問題点もある. (1得られる試料環境に制限 がある，上述した通り，導入できるガス圧力は差動 排気能力で制限を受けるため, 現状の装置では数 $\mathrm{Pa} \sim 10^{4} \mathrm{~Pa}$ のオーダーであり, 真の実環境（大気圧 雰囲気など）を再現することは難しい。 また，液体 の導入は不可能である(湿分を含んだガスは可能).

2コストが比較的高い. 本方式では TEM 本体に特 殊機能を具備するために導入コストは高くなる。ま たガス供給・排気系の多岐のパーツやその制御系が

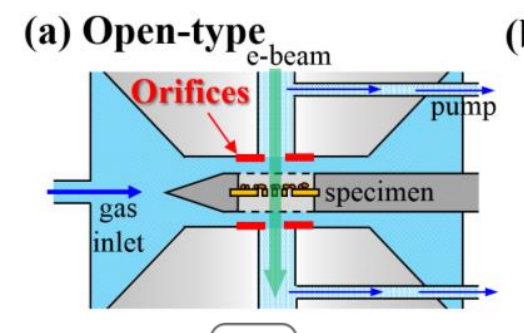

\section{(b)Membrane-type}
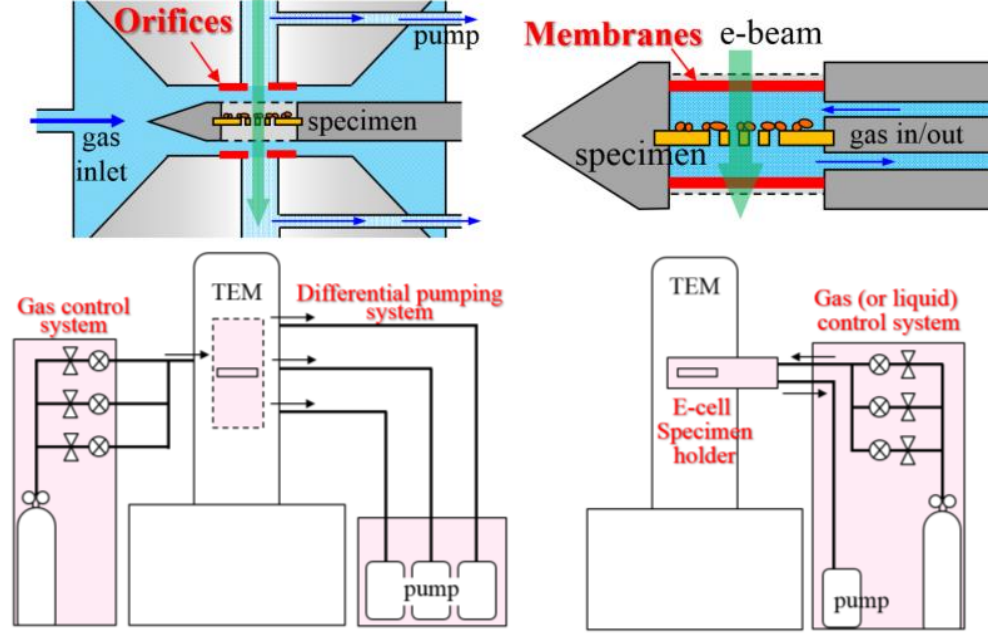

Fig. 1. Schematic illustrations of two types of environmental TEM (color online). 
トラブルを起こすリスクがあり，メンテナンス費用 なども嵩む可能性がある.

隔膜型では，TEM 本体は通常の仕様だが, 試料 ホルダーに改造を施した特殊なものを用いる。 ホル ダー軸の内部に単一[17], あるいは複数本の管を配 置して，それらを通してホルダー外部から先端付近 の試料部にガスや液の導入出を行う。試料の上下に は，電子線は通すが種々分子はシールできる隔膜を 取り付けて, 導入したガス・液を閉じ込めることが 可能となっている. 隔膜の一方は試料支持膜を兼祆 るのが一般的である，本方式では，以下に示すよう に隔膜の性質に注意が必要である。電子顕微鏡の保 守という観点から隔膜の破損によるガス・液の放出 を防ぐ必要があり，充分な機械的強度（耐圧力）お よび化学的な耐性（耐電子線・耐化学反応）を有す る材質が求められる. 加えて, 高画質・高分解能の ためには可能な限り膜厚は薄い方が良い. このよう な条件を満たす隔膜として, 過去には非晶質カーボ ン等の蒸着膜[2-5]が，最近では MEMS 技術を応用 して作製した非晶質の窒化シリコン膜[14]が主流と なっている，後者のタイプは，隔膜上に電極や配線 をパターニングすることで, 電極上の試料への通電 や電圧印加が可能である. 隔膜の厚さは，ガス導入 の場合で 10〜20 nm 程度（大気圧以上の高圧の際は 数 $10 \mathrm{~nm}$ 以上），液体では 20〜 50 nm 以上を用いる のが一般的である.これより薄い膜を使用すること はもちろん可能であるが，膜破損のリスクが大きく なる。

隔膜型の長所は以下の 2 点である. (1)幅広い試料 環境を実現できる。上述の通り, 高圧ガス雰囲気 [18]や液中[19]など実環境に近い条件をホルダー内 部に再現することが可能である. (2)開放型より低コ ストである. 特殊ホルダー一式の導入のみで,

TEM 本体には手を加えないため比較的安価である. 短所としては, (1高空間分解能の実現は難しい。こ の方式では電子線は, 隔膜（上下合わせて数 $10 \mathrm{~nm}$ 厚）を透過せねばならず，それによる電子散乱の影 響で分解能・コントラスト等の劣化が避けられない. ただし，それらを薄くすることで夜中においても結 晶格子縞の観察を実現することも可能である[20].

(2)試料ホルダーに制限がある。上述のとおり試料 は 2 枚の隔膜でサンドイッチ寸る必要があるため, その間の空間に組み込める機構は限定される. 今の ところ MEMS 膜上の配線などによる加熱と電圧印 加は可能である.

このように，開放型と隔膜型は長所・短所が互い
に相補的であり，観察対象や要求する試料雾囲気に よっていずれかを用いる。開放型のETEMはガス中 での高分解能観察に適しており, 隔膜型ETEM は液 中や大気圧雰囲気を含む実環境観察に適した方式だ と言える.

\section{3. 環境電子顕微鏡によるナノ金触媒のプロピレン 酸化反応その場観察}

金はバルク状態では触媒作用をほとんど示さない が，ナノメートルサイズにして金属酸化物上に担持 することで非常に高い触媒活性を発現することが首 都大学東京の春田らによって発見された[21]. この 触媒が活性を示すのは CO 酸化反応や NOx 分解反応 など多岐に渡るが，担体の種類によって変化すると いう特性がある[22]，その中で，我々はアナターゼ 構造の酸化チタン上に金を担持した際に発現するプ ロピレン $\left(\mathrm{C}_{3} \mathrm{H}_{6}\right)$ の酸化反応[23-25]に着目した。 上 記条件に調製された金触媒は，プロピレンオキサイ

ド $\left(\mathrm{C}_{3} \mathrm{H}_{6} \mathrm{O}\right.$; 以下，PO）を選択的に一段で生成する ことが可能である（それ以外の条件では $\mathrm{CO}_{2}$ にまで 酸化が進んでしまう）。このPO は蒸気圧が比較的 低い（室温下で約 $5 \times 10^{4} \mathrm{~Pa}$ ）ため, 周囲の圧力がそ れ以上であれば液体状態で触媒表面に残存すること になる．気体分子を電子顕微鏡で観察するのは非常 に困難であるが[11], 液体であれば像コントラスト として捉えやすい，そこで我々は，環境電子顕微鏡 を用い，セル内を蒸気圧以上に保ちながらプロピレ ン酸化反応をその場観察することで，生じた PO の 位置から反応場を特定できないかと考えた。

実験には加速電圧 $200 \mathrm{kV} の$ TEM (Hitachi, H8000) を用い，電子線が触媒反応に与える影響を極力抑え るために照射電流密度を十分低くした（Table 1）。 環境セルに導入したガスは, 主原料であるプロピレ ン，酸素，水[24]に加えて，セル内圧力を高くする ために窒素ガス（触媒反応には寄与しない）の割合 を多く配合した。

Table 1. Experimental conditions for in-situ observations of propene oxidation on gold catalyst.

\begin{tabular}{|l|l|}
\hline Specimen & $\mathrm{Au} / \mathrm{TiO}_{2}$ anatase (gold: $\left.1 \mathrm{wt} \%\right)$ \\
\hline TEM & $\mathrm{H}-8000(200 \mathrm{kV} ;$ Hitachi High Tech) \\
\hline e-beam & $0.02 \mathrm{~A} / \mathrm{cm}^{2}$ (density on specimen) \\
\hline Camera & $\mathrm{CCD}$ camera $(2-5$ frame/s) \\
\hline Gas species & $\begin{array}{c}\mathrm{C}_{3} \mathrm{H}_{6}(30 \%)+\mathrm{O}_{2}(15 \%)+\mathrm{N}_{2}(55 \%) \\
\left.\text { (including a little amount of } \mathrm{H}_{2} \mathrm{O} \text { and } \mathrm{CO}\right)\end{array}$ \\
\hline Membrane & Amorphous carbon $(8.6 \mathrm{~nm})+\mathrm{SiN}(2.0 \mathrm{~nm})$ \\
\hline Gas thickness & $\begin{array}{c}60 \mu \mathrm{m}(30 \mu \mathrm{m} \text { each at upper and lower of } \\
\text { specimen })\end{array}$ \\
\hline
\end{tabular}


プロピレンのような炭化水素分子は, TEM 観察 時に電子線により乘離してコンタミネーションの原 因となる場合が多い，そこでまず，プロピレンのみ を $6 \times 10^{2} \mathrm{~Pa}$ の圧力で導入しながら電子線を 5 分間照 射し, その前後での触媒表面の状態を比較した。

Fig. 2(a)が電子線照射前, (b)が照射後のガス中 TEM 像である.ここで, 像中央の暗コントラストの粒子 が金（粒径は約 $10 \mathrm{~nm}$ ）で，その下部の酸化チタン

(長径約 $50 \mathrm{~nm}$, 短径約 $20 \mathrm{~nm}$ の矩形) の上に担持 された状態である. (a) と(b)を見比べると, 電子線 照射の前後で両者に明瞭な差異は見られないことか ら，本実験条件下ではプロピレンによってコンタミ ネーションは生じないことが確認された。 また，プ ロピレンを除いたガス雰囲気下 $\left(\mathrm{O}_{2}+\mathrm{N}_{2}\right.$ および水分 等）においても，触媒表面には污染等の変化が現れ ないことは事前に検証している。

Fig. 3 にナノ金触媒のプロピレン酸化反応その場 TEM 観察結果を示す.それぞれは動画中からピッ クアップした像である。像中央の黒い粒子が金, そ の下部が酸化チタン担体の一部である。本実験では, TEM の対物レンズを正焦点から意図的に少しずら し，アンダーフォーカス条件で像を撮影している. そのため, 物体の外側にはデフォーカスに伴って明 コントラスト（フレネルフリンジ）が生じ，物体の エッジが強調される条件となっている. (a)は $\mathrm{O}_{2}$ と $\mathrm{N}_{2}$ を $3.2 \times 10^{4} \mathrm{~Pa}$ の圧力で導入した状態での TEM 像 で，触媒反応が起こっていないため，金あるいは酸
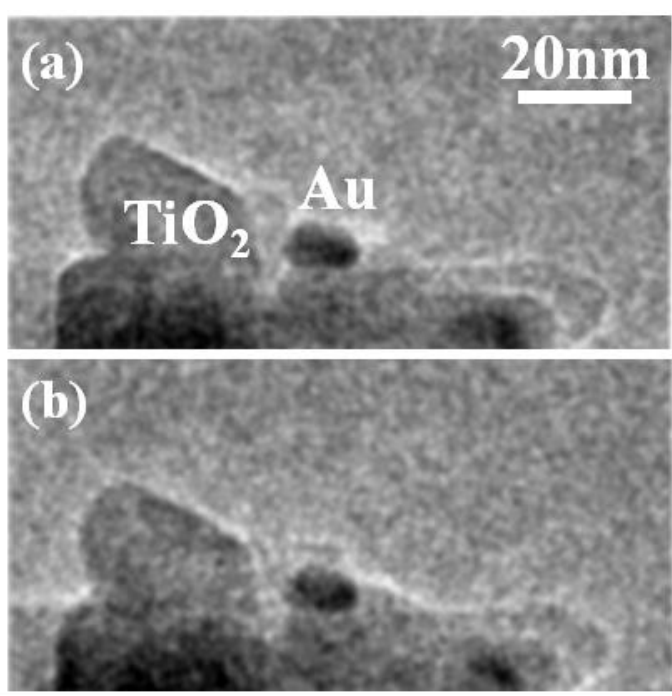

Fig. 2. TEM images of gold nanoparticulate catalysts in the gaseous environment before catalytic reactions. Almost no differences are found between images taken (a) at just starting electron beam irradiation and (b) after 5 minutes, indicating that electron beam generates no contamination on the specimen.
化チタン表面には何も現れていない.そこにプロピ レンを追加導入し全圧 $4.5 \times 10^{4} \mathrm{~Pa}$ となった状態が(b) と(c)である。これらを見ると，金と酸化チタンの 接合部周辺に触媒反応による生成物と思しき像コン トラストが現れている．上述のように，ダーフォー カス条件では物体のエッジに明コントラストが生じ るため，そこに物体（この場合はプロピレンオキサ イド）があることが明確になる。このコントラスト は定常的ではなく, 数秒ごとに出現/消滅が起こっ ていた. その後, すべてのガス供給をストップし， 排気のみを行っている状態で撮られたのが $(\mathrm{d})$ の像 で，接合部分に見られたコントラストが消失してい るのが分かる. 図 5 の結果も合わせると, (b),(c)の 像中に現れたのはコンタミネーションやガス中水分 の付着, あるいは酸化チタンが構造変化したもので
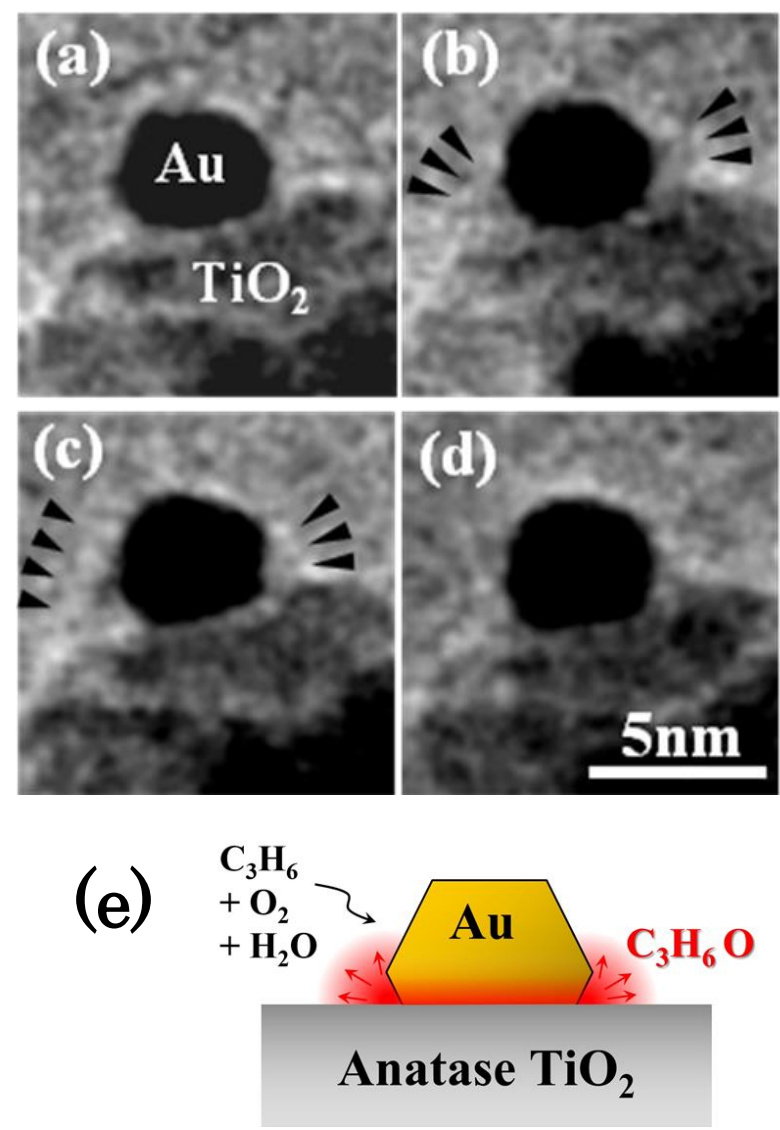

Fig.3. TEM images taken in-situ in the gaseous environment; (a) in gaseous environment of oxide and nitrogen (before starting reaction), (b) in producing propene oxide by adding propene of $4.5 \times 10^{4} \mathrm{~Pa}$ to (a), (c) after 30 seconds from (b), and (d) in vacuum condition after evacuating gases. Catalytic reaction product appear at the perimeter of gold and $\mathrm{TiO}_{2}$ support as shown by arrow heads in (b) and (c). (e) Schematic illustration of catalytic reaction model of propene oxide formation. (color online) 


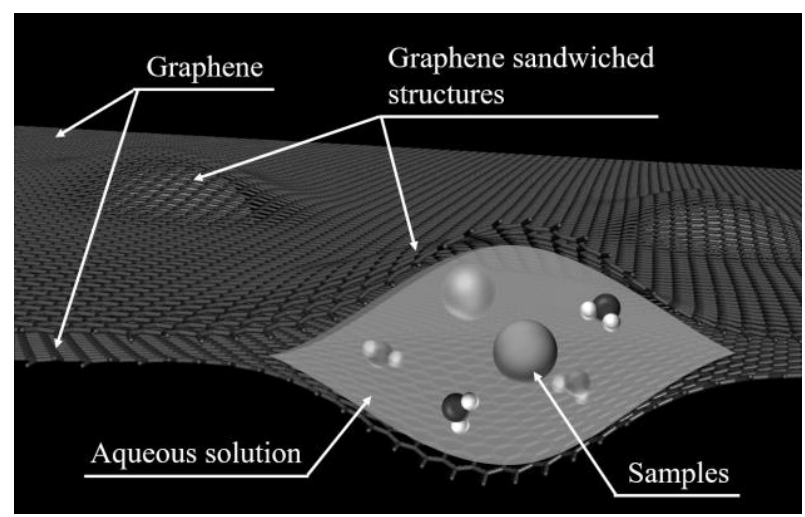

Fig. 4. Schematic illustration of a graphene sandwich method.

はなく, 触媒反応によって生じた物質と考えられ る.

反応雾囲気之の場観察中，排気側経路に設けてい る質量分析器によるガス分析も同時に行っていた. PO に相当寸る質量数のガス分圧はプロピレンを導 入すると 3 倍以上に増加した. また，ガス供給をや めてセル内の圧力が蒸気圧以下に下がると, $\mathrm{PO}$ 分 圧はそこからさらに約 5 倍（トータルで反応前の 15 倍）上昇した。これは, ガス雾囲気下では生成した PO が触媒表面に堆積しており, ガスがなくなり周 囲圧力が下がると気化して排気側に流れたためであ ると考えられる。この結果は, TEM 観察された生 成物が PO であることを示唆するものである. 以上 の結果から, 反応生成物は金と酸化チタンの接合界 面周囲で発生していることから，そこがナノ金触媒 の反応場だと考えられる.これは春田らによって提 唱されている反応モデルとも一致する結果である [21]. ただし，生成物が POかどうかはEELS等の局 所領域分析が可能な手法を用いて同定を行う必要が ある。

\section{4. グラフェンを用いた新しい隔膜型 ETEM}

第 2 節に，隔膜型 ETEM の欠点として空間分解能 が良くないことを挙げたが，これを克服する新しい 技術が最近開発された. 分解能向上には隔膜と液層 を薄くすることが肝要である，そこで原子 1 層とい う究極の極薄膜である単層グラフェンを隔膜とし, 2 枚のグラフェン・シートで液体（および試料）を 挟み込んでパッキングするのが“グラフェン・サン ドイッチ”と呼ばれる方法である（Fig. 4）[25-27]. この手法は，隔膜が極薄であるだけでなく，ファン デルワールスカで密接するグラフェン層間に取り込 める液量が少量のため, 液層も非常に薄くなる（数 $10 \mathrm{~nm}$ 以下; 通常の液体 ETEM では数 $100 \mathrm{~nm}$ 数 $\mu \mathrm{m})$. これによって, 液中でありながら原子分解能 での観察を実現している，さらに，液体試料をパッ クしたグラフェン・サンドイッチは上述した特殊な 試料ホルダーに搭載する必要はなく, 一般的な金属 メッシュに載せて汎用の試料ホルダーで観察できる ため非常に簡便な手法と言える。ただし，現状では 電極・配線のパターニングや, 液の循環（配管を通 したフロー）は出来ない. また，グラフェンが電子 ビームで破損しないように, 電子線の加速電圧は基 本的には $80 \mathrm{kV}$ 以下に限定される.

本手法の応用としては, 液中での電子線誘起結晶 成長の動的観察 [25]やリチウム化反応 [26]といった 無機材料の諸現象解析が主であったが, 最近はタン パク質などの微小有機物の観察へも応用されつつあ る. 結晶化が困難なタンパク質の構造解析にはクラ イオ TEM が用いられているが, 試料を水の中に閉 じ込めて支持しているため, 水層での電子線散乱・ 氷分子像の重畳などが起こり, 特に微小なタンパク 質の場合, 充分な精度 - 分解能での解析は大変難し かった。これに対し，GLC では薄く且つ流動して いる液中に試料を置くため, 上記の問題が発生しな
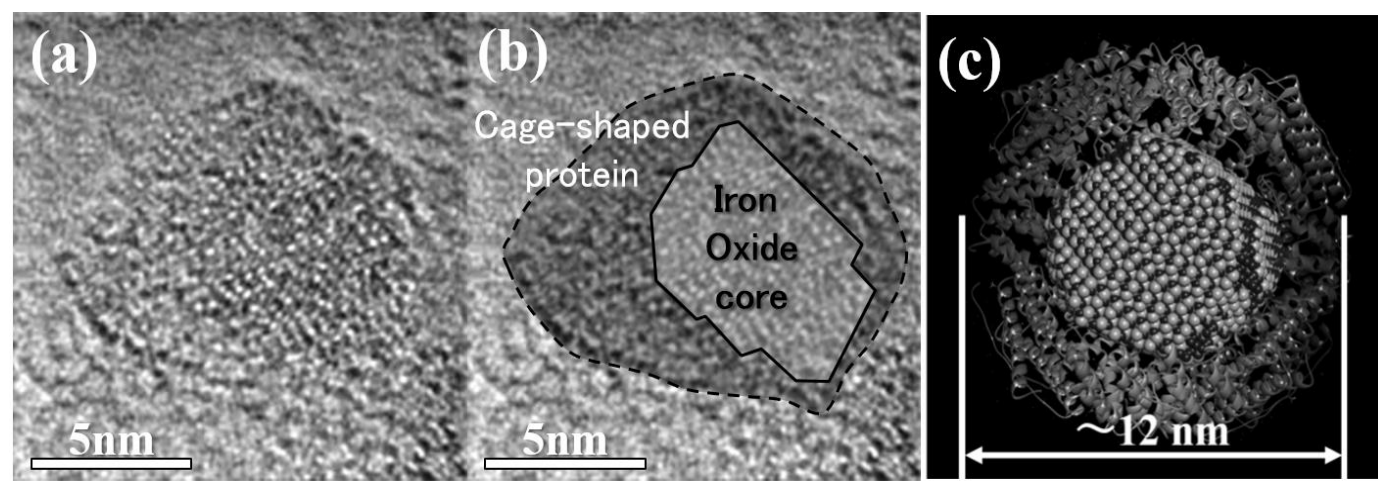

Fig. 5. High-resolution TEM observation of a ferritin particle with the graphene sandwich method. (a) Observed TEM image, (b) its structural explanation and (c) structural model of a ferritin. 
い. また, 動的挙動の解析にも有用である. その応 用例として, Fig. 5 にフェリチン粒子の液中観察 TEM 像を示す [28]. フェリチンは生体内で鉄を貯蔵 するためのタンパク質であり，鎖状高分子が中空か ご状構造を形成しており，その内部に鉄粒子を内包 することが出来る. 大きさは $10 \mathrm{~nm}$ 程度と小さいた め, 従来法で撮影した単一画像では内部の鉄は見え ても, 周囲を取り巻くかご形構造の直視は非常に難 しかった.これに対し，Fig. 5 では中央の鉄コアを 包むタンパク質由来部分が明瞭に観察されている. 現状では，観察時の電子線照射の影響で本来の構造 が保たれていない可能性があるが，低ダメージ観察 を行うことで詳細な構造を動的に捉える事が可能に なると期待されている.

\section{4.まとめ}

本稿では, 各種材料を動作環境に近い状況で観察 できる環境電子顕微鏡技術に付いて詳述した．特に， より実環境に近い条件が実現可能な“隔膜型”の環境 電子顕微鏡を用いた応用研究例を紹介した.

ナノ金触媒のプロピレン酸化反応その場観察を行 った結果, プロピレンオキサイドと考えられる生成 物が金と酸化チタンの接合界面周囲に現れた。この 結果は，接合界面の周囲がナノ金触媒の反応場であ るということを示唆するものである.

また，隔膜型の環境電子顕微鏡の弱点である，隔 膜による電子線散乱に伴う分解能劣化を解決できる グラフェン・サンドイッチ法を開発した。本手法を 用いることで, フェリチンの高分解能観察に成功し た.

環境電子顕微鏡は, 再現できる環境をより現実に 近づけるために現在も技術開発が進められている.

特に, MEMS 技術の進歩により, 複雑な機構を微 小なシリコンチップ上に構築することができるよう になったのが大きく寄与している，それを試料ホル ダー先端に搭載することで, 試料に対して様々な刺 激 (加熱, 冷却, 電圧印加, 引っ張り, 圧縮など) を与えながら, その挙動を直接観察し, かつ刺激の 大きさを計測することも可能となってきている，そ のような技術発展により, 様々な物理現象をナノあ るいは原子レベルで可視化することが出来つつあり， 将来の材料開発に大きく貢献するものと期待されて いる.

\section{5. 参考文献}

[ 1] H. Hashimoto, J. Electron Microsc. 9, 130 (1960).
[ 2] H. G. Heide, Die Naturwissenschaften 14, 313 (1960).

[3] H. G. Heide, J. Cell Biol. 13, 147 (1962).

[4] A. Fukami, K. Fukushima, A. Ishikawa and K. Ohi, Proc. 45th Annual Meeting of the Electron Microsc. Soc. America, 142 (1987).

[5] A. Ishikawa, K. Fukushima and A. Fukami, J. Electron Microsc. 38, 316 (1989).

[ 6] R. Sharma, Miscrosc. Microanal. 7, 494 (2001).

[7] P. A. Crozier, R. Wang and R. Sharma, Ultramicroscopy 108, 1432 (2008).

[ 8] P. L. Gai and E. D. Boyes, Microsc. Res. Tech. 72, 153 (2009).

[9] P. L. Hansen, J. B. Wagner, S. Helveg, J. R. Rostrup-Nielsen, B. S. Clausen and H. Topsoe, Science 295, 2053 (2002).

[10] S. Takeda and H. Yoshida, Microscopy 62, 193 (2013).

[11] H. Yoshida, Y. Kuwauchi, J. R. Jinschek, K. Sun, S. Tanaka, M. Kohyama, S. Shimada, M. Haruta, and S. Takeda, Science 335, 317 (2012).

[12] T. L. Daulton, B. J. Little, K. Lowe and J. Jones-Meehan, Miscrosc. Microanal. 7, 470 (2001).

[13] S. Giorgio, S. S. Joao, S. Nitsche, D. Chaudanson, G. Sitja and C. R. Henry, Ultramicroscopy 106, 503 (2006).

[14] J. F. Creemer, S. Helveg, G. H. Hoveling, S. Ullmann, A. M. Molenbroek, P. M. Sarro and H. W. Zandbergen, Ultramicroscopy 108, 993 (2008).

[15] K. Ueda, T. Kawasaki, H. Hasegawa, T. Tanji and M. Ichihashi, Surf. Interface Anal. 40, 1725 (2008).

[16] T. Kawasaki, K. Ueda, M. Ichihashi and T. Tanji, Rev. Sci. Instrum. 80, 101101 (2009).

[17] 川㠃忠寬，特許第 5437612 号 (Dec. 2013).

[18] T. Kawasaki, T. Miura, Z. Cui, H. Tsutsui, T. Matsutani and T.Tanji, Microsc. Microanal. 17(s2), 534 (2011).

[19] N. Jonge, F. M. Ross, Nat. Nanotech 6, 695 (2011).

[20] H. G. Liao, D. Zherebetskyy, H. Xin, C. Czarnik, P. Ercius, H. Elmlund, M. Pan, L. Wang, and H. Zheng, Science 345, 916 (2014).

[21] M. Haruta, N. Yamada, T. Kobayashi and S. Iijima, J. Catal. 115, 301 (1989).

[22] S. Tsubota, M. Haruta, T. Kobayashi, A. Ueda and Y. Nakahara, Stud. Surf. Sci. Catal. 63, 695 (1991).

[23] T. Hayashi, K. Tanaka and M. Haruta, J. Catal. 178, 
566 (1998).

[24] M. Ojeda and E. Iglesia, Chem. Commun. 325 (2009).

[25] J. M. Yuk, J. Park, P. Ercius, K. Kim, D. J. Hellebusch, M. F. Crommie, J. Y. Lee, A. Zettl and A. P. Alivisatos, Science 336, 61 (2012).

[26] J. M. Yuk, H. K. Seo, J. W. Choi, and J. Y. Lee, ACS Nano, 8, 7478 (2014).

[27] Y. Sasaki, R. Kitaura, J. M. Yuk, A. Zettl and H. Shinohara, Chem. Phys. Lett. 650, 107 (2016).

[28] 佐々木祐生, 川﨑忠寛, 越野雅至, 佐藤主税, 末永和知, 第 78 回応用物理学会秋季学術講演 会予稿集，(2017).

\section{査読コメント，質疑応答}

査読者 1 下村 勝（静岡大学）

本論文ではETEMの現状に関する解説と，金ナノ 触媒及びグラフェン・サンドウィッチ法によるその 場観察の結果について述べています。 JSA 誌の解説 記事として適切な内容であり, 以下の軽微な修正の 後, 出版可能であると判断されます。

\section{[查読者 1-1]}

タイトルの「反応挙動」という意味で Fig. 3 は本 論文の主要な結果であると思われますが，動画でな いため「像コントラスト」の違いが見えにくくなっ ています。黒矢印で示す部分ということで説明して いただいていますが，(b)や(c)では，むしろ白い部分 が増えているように見えます。生成物のポイントを 正確に示す必要があるのではないかと思います。特 に, Fig. 3 において, 金微粒子周辺だけでなく, $\mathrm{TiO}_{2}$ 付近のコントラストも変わっているように見えます ので，どの構造を議論しているのか明確にしていた だくと, 読者はスムーズに理解ができると思います.

\section{[著者]}

今回の観察対象である液状プロピレンオキサイド は軽元素で構成されていることから，そもそもコン トラストが低いものです。そのため，本研究では意 図的にフォーカスを少しずらし物体の外側にフレネ ルフリンジが生じる条件にしています。そうするこ とで，物体の端部が明コントラストになりエッジ強 調されます。例えば，Fig. 3(c)の矢印の先は，その 明コントラストを指しており，そこが発生したプロ ピレンオキサイドの端部であることを示しています。 このような明コントラストは反応前の(a)や反応後 の(d)には見られません.

$\mathrm{TiO}_{2}$ 付近のコントラスト変化については，観察中 の電子ビーム照射の影響により， $\mathrm{TiO}_{2}$ の位置・角度 が微小変化したこと, 結晶構造がダメージにより少 し壊れかけていることが影響していると判断してお ります。これは, $\mathrm{Au} / \mathrm{TiO}_{2}$ 試料の $\mathrm{TEM}$ 観察時にまま 見られる現象です。

以上の点について，本文にも明記するように修正 いたしました。また，視覚的に分かりやすいように， モデル図を新たに Fig. 3(e)として追加いたしまし た.

査読者 2 橋本 哲（JFEテクノリサーチ）

本解説記事は，実環境に近い条件で触媒反応を， 
汎用透過電子顕微鏡（TEM）を用いても解析できる ようになってきたことを示す, 大変有意義な解説で あり，本誌に掲載すべきものです，特に, 化学工業 で有用な溶液中での触媒反応の解析が可能になって きた点は, 重要と思います。

\section{[査読者 2-1]}

TEM 像使ってはいても, 像解釈に馴染みがない 読者（本誌の読者は表面分析主体の方が多い）の理 解を進めるため, TEM 技術の研究者にとって自明 な像の見方についても，例えば，画像のどこを見れ ばよいのかなど，簡単で結構ですから，加筆してい ただけませんか.

\section{[著者]}

TEM 像の解釈については，ご指摘頂いた点を踏 まえて加筆を致しました. 特に, 像中での金粒子, および担体がどの部分に相当するのか，発生したプ ロピレンオキサイドがどこを見れば分かるかといっ た点について加筆しました.

\section{[查読者 2-2]}

【P. 247 左コラム】 “ガス・液層を透過せねばなら ず，分解能・コントラストの低下が避けられな い.”と記述されていますが，開放型でも，この散 乱については圧力が同じなら，事情は同じと思いま す。これは，隔膜型の方が導入圧力を高められるた めであり，同じ圧力なら，電子が通過する部分が小 さい隔膜型の方が有利なのではないでしょうか?

\section{[著者]}

ご指摘の通り，同じガス圧力であれば開放型・隔 膜型に依らず，ガスによる像劣化は同様に起こりま す. また, 開放型の方が, 隔膜型に比べて, ガス層 の厚さ（電子ビームが通過するガス領域の距離）が 小さい点が有利なのも仰る通りです.

ただし，後者は隔膜による影響が重畳します．ガ スと隔膜（固体）の密度は 3 桁程度異なるため, 隔 膜による像劣化は, ガスによる劣化の 1000 倍程度 ということになります。したがって，ガス圧が低い

（開放型のように低くせざるを得ない）場合，ガス による散乱の影響は相対的に小さくなり，隔膜の有 無が像質を大きく左右することになります.

上記の点から，本文ではガス・液層による散乱に ついては言及せず, “隔膜の存在によって像質が劣 化する”という点に絞って記述することで, 開放型
との差異を明確にしております。

\section{[査読者 2-3]}

【p. 245 右コラム】触媒反応によって生成した PO は，液状で触媒表面に存在しているのですね.

その為かと思いますが，（おそらく担体の $\mathrm{TiO}_{2}$ や液状の PO の存在のため), $\mathrm{Au}$ に吸着している生 成物のコントラストがどれなのか，よくわかりませ んでした（例えば，（b）の右側真ん中の矢印の先に は，明るいコントラストが見られ，左の真ん中の矢 印の先には暗いコントラストが見えています。逆に， (a)や(d)でも，白い点状のコントラストが観察され ています，）。㧍そらく，動画では PO の生成・解 離が良く判ると思いますが，TEM 像に慣れていな い読者が多いので，どこを見れば良いのか，もう少 し，加筆していただけませんか?

\section{[著者]}

ご指摘の通り, 触媒反応で生成した PO は, 液状 で触媒表面の金/酸化チタン接合界面周囲に存在し ています。これが Fig. 3 の像から読み取るのが困難 である，という指摘をもう一方の査読者からも指摘 頂きました．PO は軽元素で構成されているため像 コントラストしてはほとんど現れません。 そこで, デフォーカスを大きめにすることで，物体の端部に 明コントラストが生じるようにすることでエッジ強 調して PO の生成を像として捉えております。また， その旨を本文に追記いたしました。（詳細は査読者 1-1 の回答参照)

\section{[査読者 2-4]}

【p. 248 右コラム】“そこからさらに約 5 倍上昇し た.”と書かれていますが， 5 倍の基準は最初の分 圧でしょうか? それとも， 3 倍になった分圧の 5 倍, 寸なわち初期の 15 倍のいずれでしょうか? あるいは，ネットの PO 量（妨害分を差し引いたプ ロピレン導入後の真のPO 増分）に対する 5 倍でし ようか?

\section{[著者]}

まずプロピレンを導入して反応が開始することで 3 倍に, その後, 周囲の圧力が下がることで揮発し て検出される分が，そこから更に 5 倍ですので，卜 ータルでは初期の 15 倍になっています。 その旨を 本文にも追記いたしました。 


\section{[查読者 2-5]}

【P. 249 左コラム】 “生成物が PO であるかどうかは EELS などによる同定が必要”と記述されています。 ガス分析により反応生成物は PO と同定されている のにもかかわらず，あえて，TEM-EELS を取り上げ ていらっしゃいます。この部分に，書かれていない, 川崎様の思いがある様に感じました。

そうでなければ結構ですが，取り上げた理由を， 簡単に記述していただけませんか? 例えば，ガス 分析のような分析では吸着・解離などの表面反応は 見えていない, TEM 像だけでは, ナノレベルの分 子種・電子状態などは，素人からも考えつきますが， ご専門の立場から，簡単に示していただけません か?

\section{[著者]}

仰るとおり，ガス分析により PO が発生している ことは確認しております。しかし，あくまでも試料 全体で PO が生成されているだけで，“今見てい る”生成物が PO であることは証明できていません (視野外で PO が生成されていて, 観察領域では別 の物質が生じている可能性はゼロではない）。その ため, 観察中に生じた物質を, 局所的に分析するこ とが必要だという意味で EELS 分析について言及い たしました.

その旨を本文中にも追記いたしました。

\section{[查読者 2-6]}

【P. 249 右コラム】“明瞭に観察されている.”と 書かれています．たんぱく質がどれであるか，また $\mathrm{Fe}$ コアがじこに・どう見えているかを, 簡単に, 加筆していただけませんか?

(高分解能構造像を含め, TEM 像を見慣れない読 者が多いので，理解を進めるためです，中央の像が， 解䣋の結果と思います。)

また，右のモデル図で鉄コアの原子として，二種 類の大きさの原子が描かれています，実は，異なる 元素から構成されているのでしょうか？それとも， 見やすく寸るため，原子面の違いなどを示している のでしょうか? 後者なら特に記述していただく必 要はありません。しかし, 構造の特徵に起因する前 者の場合, その違いを明示してください。

\section{[著者]}

コアは鉄ではなく酸化鉄です，そのため，モデル 図のコアに色が異なる 2 種類の原子が含まれている
のは，それぞれ鉄原子と酸素原子に当たります。

\section{[査読者 2-7]}

微粒子のファセットの同定について, Fig. 5 のモ デル図で，鉄コアの二つのファセット面とその境界 の綾が示されています。1 方向から観察した投影像 である TEM 像から，この様な立体構造どうやって 決定されたのでしょうか?

\section{[著者]}

最後の微粒子のファセット同定についてですが， Fig. 5 右のモデル図は, 左の TEM 像から得られたも のではなく, $\mathrm{Fe}_{2} \mathrm{O}_{3}$ 結晶のシンプルな多面体粒子を モデルとして描いただけのものとなります。ご指摘 のように，1枚の TEM像からモデルのような立体構 造の情報を得ることはできません（多方向からの撮 影像が必要です)． 